\section{NOVÁ TECHNOLOGIE V INTENZIVNÍ PÉČI POMÁHÁ VZDÁLENĚ SLEDOVAT PACIENTY NEJEN S COVID-19}

\section{Lenka Vysloužilová, Václav Zvoníček, František Duška, Jan Jirman, Jan Kubr, Lenka Lhotská, Miroslav Macík, Milan Němý, Eliška Niebauerová, Lukáš Povišer, Martin Samek, Jakub Vaněk}

\begin{abstract}
Anotace
Systém VENT-CONNECT je nová telemedicínská aplikace, která umožňuje vzdálené sledování obrazovek plicních ventilátorů a monitorů vitálních funkcí, jejichž datové výstupy nejsou přímo připojeny do nemocničního informačního systému. Systém umožňuje lékařům častější kontrolu parametrů umělé plicní ventilace u pacientů a tím i přesnější nastavení parametrů ventilátoru v průběhu léčby pacienta, což zlepšuje péči o pacienta. Obecně Ize systém použít na prístroje, u kterých je žádoucí vzdáleně sledovat obrazovku přístroje spolu se sledováním trendu vývoje parametrů př́stroje. Systém má velký potenciál jak během pandemie Covid-19, tak i za běžného provozu JIP.
\end{abstract}

\section{Klíčová slova \\ telemedicína, Umělá plicní ventilace, Intenzivní péče}

\section{1 Úvod}

Mechanická ventilace (MV) je klíčovou orgánovou podporou poskytovanou na jednotkách intenzivní péče (JIP). Přestože může být $M V$ život zachraňující, není sama o sobě léčebnou metodou. Spíše pomáhá získat čas pro další léčbu, aby došlo k zlepšení stavu pacienta, který si ventilaci vyžádal. Jakékoli suboptimální nastavení mechanického ventilátoru může způsobit poškození plic, které se nazývá ventilátorem indukované poškození plic (VILI) [Slutsky 2013]. To sahá od vzácného klasického barotraumatu (např. pneumotoraxu způsobeného přímým poškozením plicního parenchymu $\mathrm{v}$ důsledku nadměrného tlaku) až po nenápadné, ale mnohem častější biotrauma (kdy dochází k vyvolání zánětu a obraz pacienta je podobný ARDS). Jakékoli předcházející trauma plic zvyšuje náchylnost k dalšímu poškození vyvolanému ventilátorem [Dreyfuss 1998].

Klasické studie opakovaně prokázaly souvislost zhoršených výsledků s dechovými objemy $>6 \mathrm{ml} / \mathrm{kg}$ [ARDSNet 2000], tlaky $>30$ mbars [Yasuda, 2021], hnacím tlakem > 14 mbars [Amato, 2015], vysokým mechanickým výkonem [Gattinoni 2001; Costa 2021] a interferencí pacienta s ventilátorem [Vignaux 2009]. Ve skutečnosti většina klinických lékařů nastavuje a vhodně upravuje parametry nastavení plicního ventilátoru u sedovaných a paralyzovaných pacientů $v$ časné fázi po intubaci. Nicméně výše uvedené parametry jsou důsledkem nastavení ventilátoru a fyziologických parametrů pacienta, které se často mění. Změny fyziologie pacientů zahrnují mimo jiné následující:

- Respirační drive a spontánní inspirační úsilí (např. v důsledku kolísající úrovně sedace nebo stavu kyselé báze).

- Poddajnost dýchacího systému v důsledku rozvíjejícího se základního onemocnění plicního parenchymu nebo náboru či výdeje, polohování pacienta (např. pronace).

- Odpor dýchacích cest, a to včetně umělých dýchacích cest (např. zalomení trubice, kolísavý odpor výměníků tepla a vlhkosti, změny průměru endotracheální trubice exsikovanými sekrety) nebo dýchacích cest pacienta (např. bronchospasmus).

- Změny spotřeby $\mathrm{O}_{2}$ a produkce $\mathrm{CO}_{2}$ (např. dusivý třes nebo horečka).
Udržování optimálního nastavení MV vyžaduje časté nastavování ventilátoru podle měnících se fyziologických parametrů pacienta. Ve skutečnosti tomu tak často není a četné observační studie dokumentovaly, že značná část kriticky nemocných pacientů je ventilována mimo bezpečnostními údaji podporované limity [Laffez, 2016 - studie LUNGSAFE].

Během pandemie COVID-19, kdy jsou pacienti izolováni v izolačních boxech a personál musí nosit plné ochranné vybavení a je pracovně přetížený, může docházet ke zhoršení pozornosti personálu k aktuálnímu nastavení ventilátorů, a tím mohou být pacienti vystaveni zvýšenému riziku VILI. Neexistuje totiž žádné daty podložené doporučení, jak často by se mělo věnovat pozornost nastavení ventilátoru a jak často by se mělo upravovat.

Domníváme se, že technické řešení, které odstraní výše zmíněné bariéry komplikující častou kontrolu parametrů umělé plicní ventilace, může vést $k$ vyšší frekvenci kontroly a prípadné korekce parametrů umělé plicní ventilace. $V$ důsledku by se měla prodloužit doba, po kterou má pacient optimální nastavení parametrů plicní ventilace, což by mělo přispět k lepším výsledkům léčby.

Moderní nemocniční informační systémy umožňují zpracování datových výstupů z různých přístrojů používaných při péči o pacienty, kteři vyžadují intenzivní péči. Jedná se zejména o monitory životních funkcí, plicní ventilátory, dialýzu, infuzní sety, prístroje ECMO, analyzátor hemodynamiky apod. Informace, které tyto prístroje poskytují prostřednictvím svých datových výstupů ale mohou být nedostatečné nebo nevyhovující z následujících důvodů:

- Některé údaje nejsou k dispozici.

- Formát dat poskytovaný konkrétním přístrojem není

k dispozici nebo je jeho poskytnutí podmíněno vysokým poplatkem.

- Nevhodná modalita výstupu.

Příkladem moderního nemocničního systému umožňující zpracování datových výstupů z prístrojů od různých výrobců je systém Metavize [https://www.imd-soft.com]. V př́padě plicních ventilátorů tento systém bohužel nepřenáśi dostatek dat, protože nedisponuje daty $\mathrm{k}$ detailnímu popisu průběhu křivky tlaku a průtoku. Oproti tomu, informace zobrazené prímo na displeji plicního ventilátoru lékařům umožňují snadnou orientaci a rychlou detekci nežádoucích stavů prípadně suboptimálně nastavených parametrů umělé plicní ventilace. Potřeba umožnit vzdáleně nahlížet na parametry plicních ventilátorů formou "jako by člověk stál" hned vedle príistroje nás motivovala k vývoji systému VentConnect.

\section{Návrh systému VentConnect}

V reakci na předpokládanou bližící se podzimní vlnu onemocnění COVID-19 v říjnu 2020 bylo ČVUT osloveno Klinikou anestegiologie a resuscitace Fakultní nemocnicí Královské Vinohrady s žádostí o pomoc s monitorováním kriticky nemocných pacientů připojených na umělou plicní ventilaci v infekčním prostředí.

Navázali jsme na koncept řešení, který na ČVUT vznikl již v první polovině roku 2020. Během několika málo dnů vznik první prototyp zařízení, který umožňoval pomocí kamery přenášet obraz z plicního ventilátoru pomocí Wifi sítě na notebook, který byl umístěn na lékařském pokoji. Součástí prototypu byla i první verze software systému, který byl schopen zprostředkovat i obousměrnou hlasovou komunikaci. Při vývoji prototypu jsme využili HW komponenty, které jsou snadno dostupné na trhu. Základem řešení byl mikropočítač Raspberry Pi a rozšiřující moduly umožňující hlasovou komunikaci. Kameru jsme umístili na flexibilní rameno, které bylo původně součásti LED lampičky. 


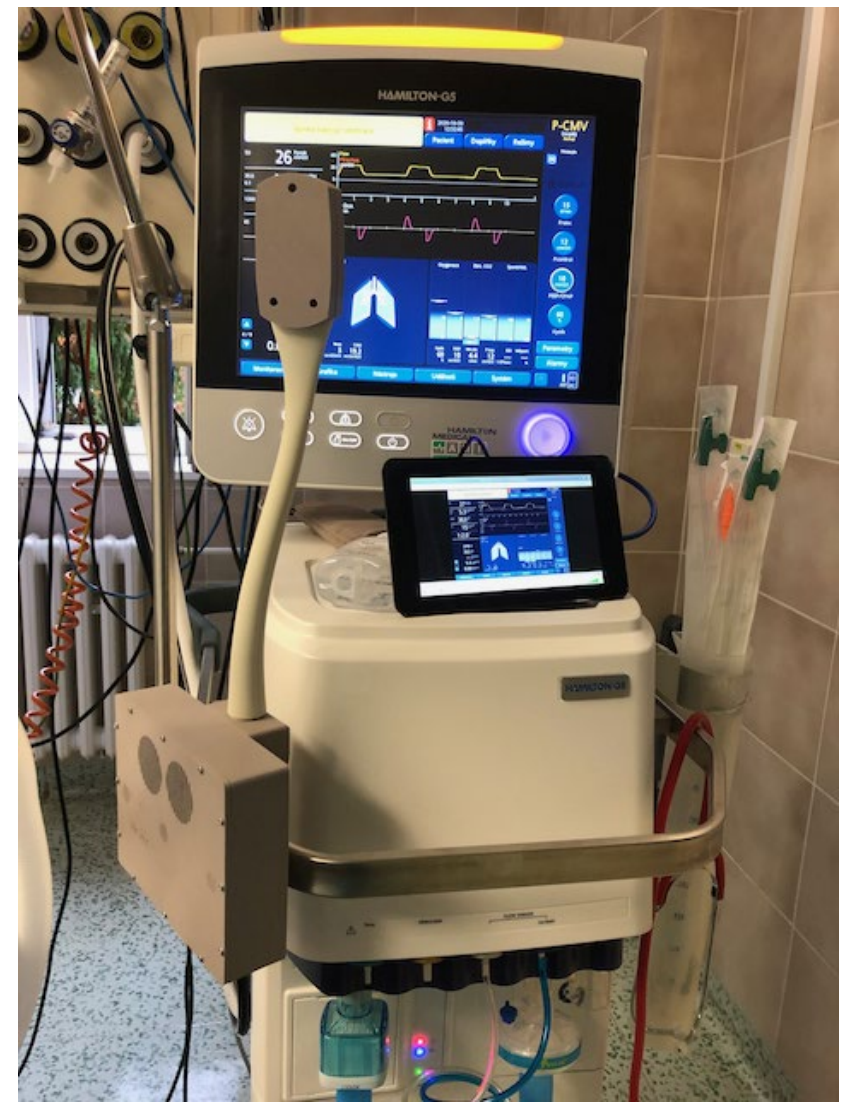

Obrázek 1 - První prototyp systému VentConnect předvedený v nemocnici

Obrázek (obr. 1.) ukazuje jedno z prvních testování prototypu u ventilátoru, který byl připojen na umělou plíci.

Prostřednictvím tohoto prototypu se nám podařilo prokázat prípadnou použitelnost řešení v prostředí jednotek intenzivní péče na pozadí probíhající podzimní vlny onemocnění Covid-19. $V$ průběhu testování prototypů v reálném prostředí jsme sbírali a analyzovali potřeby uživatelů $v$ tu dobu pro nás velmi neznámého prostředí jednotek intenzivní péče.

Během listopadu jsme postupně ladili software a narazili na problém $s$ kvalitou přenosu pomocí Wifi sítě. Reagovali jsme doplněním jednotky VentUnit o lepší Wifi anténu. Na začátku prosince došlo k rapidnímu zlepšení pandemie, skončila první podzimní vlna, pacientů $v$ nemocnici rychle ubylo, ale bohužel následovalo velmi optimistické rozvolnění opatření a Vánoce. Pro projekt nastalo nové období, dostali jsme se na pracoviště, kde jsme mohli začít zkoušet zařízení v rámci klasické kabelové sítě zcela oddělené od sítě nemocnice.

$V$ této době došlo i na výraznou změnu koncepce, zcela jsme opustili koncept komunikace pomocí zařízení a soustředili se pouze na přenos obrazové informace a zásadní novinkou byl záznam krátkých sekvencí obrazovek plicních ventilátorů každých 15 minut. Díky tomu lékaři získali přehled o vývoji parametrů v čase, což se ukázalo jako klíčová vlastnost systému. Přehrávání záznamů v prohlížeči mobilního telefonu byl bonus pro uživatelský komfort lékařů.

Během ledna jsme sepsali žádost $k$ etické komisi nemocnice a od začátku března jsme mohli zkušebně monitorovat stav pacientů na jednotlivých lůžkách. Postupně jsme vybavili systémem celé jedno oddělení a přidali do systému sledování monitoru životních funkcí. Na konci dubna jsme získali podporu projektu od ministerstva průmyslu a obchodu v programu Czech Rise Up 2.0 - Výzkum proti COVID-19.

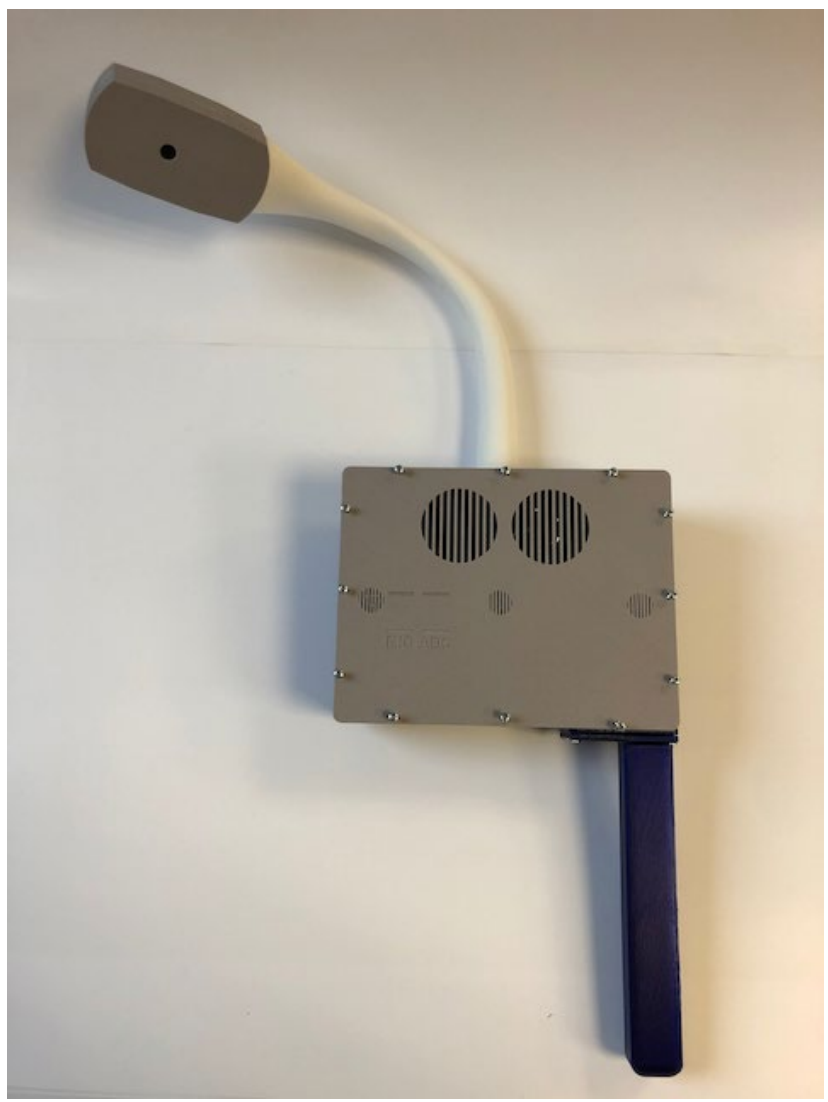

Obrázek 2 - Druhý prototyp jednotky VentUnit doplněný o výkonnější Wifi komunikaci

\section{Popis systému VentConnect}

Výsledná verze systému VentConnect se skládá ze základních komponent VentUnit, sítové infrastruktury a úložiště dat. Komponenta VentUnit je připojena kabelem HDMI k plicnímu ventilátoru a přenáší digitální obraz z ventilátoru nebo pomocí kamery plicní ventilátor sleduje.

VentUnit je jediná součást systému, která je blízko pacienta, ale žádným způsobem s ním neinteraguje a je navržena tak, aby ani nemohla žádným způsobem ovlivnit funkci plicního ventilátoru. Komponenta VENT-UNIT je napájena nízkým napětím z externího certifikovaného zdroje a připojuje se do oddělené informační sítě bud' ethernetovým kabelem nebo pomocí pro tento účel vytvořené privátní WiFi sítě.

Systém využívá obrazový výstup z plicního ventilátoru nebo kamery a odesílá získaný obraz na server prostřednictvím internetové sítě oddělené od nemocniční sítě. Blokové schéma systému s různými typy vstupů a sítí je znázorněno na (obr. 3).

\section{Software}

Stejně jako celý systém VentConnect i software pro něj vyvíjený prošel postupným vývojem. Systém VentConnect podporuje dva způsoby sledování ventilátorů - živé a ze záznamu. Zařízení VentUnit dokážou fungovat oběma způsoby kromě prípadu, kdy by nastal souběh nahrávání a streamování. Pro účely živého přenosu obrazu byla vytvořena desktopová aplikace VentClient. $\checkmark$ ní je možné přepínat mezi několika ventilátory a také hlasově komunikovat s personálem u pacienta. Po výběru ventilátoru, který chceme sledovat, se aplikace připojí pomocí počítačové sítě k jednotce VentUnit. Protokolem SSH (Secure Shell) se sestaví řídící spojení a tímto kanálem následně aplikace spouští obrazový a případně hlasový stream. 
Nahrávky vznikají odlišných způsobem. Jednotka VentUnit každých 15 minut samostatně zaznamenávají krátký klip (10-15 sekund). Ten pak pomocí protokolu SSH nahrávají na server. Tyto záznamy uložené na serveru Ize pomocí webového prohlížeče procházet a prohlížet historii nahrávek z konkrétního zařízení. Ukázka snímku obrazovky je na obrázku (obr. 4). V případě, že se nepodaří záznam pořídit, odesílají zařízení na server chybovou hlášku, která se zobrazí uživateli místo nahrávky, příkladem chybové hlášky je např́klad odpojený ventilátor od jednotky VentUnit.

Vždy, když to bylo výhodné, jsme využili již existující technologie. Pro živé přenosy jsme použili sítový protokol RTP a pro kompresi zvuku a videa kodeky H.264 a Opus. Velmi nám pomo$\mathrm{hl}$ otevřený framework GStreamer [https://gstreamer.freedesktop.org], který nám umožnil řešení sestavit z předpřipravených komponent. Použití existujících knihoven nám umožnilo rychlý vývoj systému. Zatím ale např́klad nebylo možné sledovat jeden ventilátor $z$ vícero klientů - pouze jeden klient dokázal naráz přistupovat $k$ obrazu $z$ HDMI. To plánujeme $v$ dalších verzích vyřešit použitím „agenta“, který na VentUnit poběží neustále a bude přeposílat obraz všem klientům současně a tím umožní živé sledování jednoho ventilátoru z více míst současně.

Cílovým stavem pro vývoj softwaru, který stále probíhá, je umožnit lékaři se pomocí mobilního telefonu, tabletu nebo počítače odkudkoliv připojit do systému a sledovat živý přenos z obrazovky ventilátoru, monitoru životních funkcí nebo jiného připojeného zařízení. Cílem je umožnit sledování více obrazovek najednou, např́klad vedle sebe na jedné webové stránce. To umožní sledovat data z plicního ventilátoru a monitoru životních funkcí nebo i dalšího prístroje $u$ jednoho pacienta. $Z$ hlediska dlouhodobého sledování pacientů je důležitá archivace dat z obrazovek a důsledná anonymizace dat včetně vyřešení prístupů jednotlivých uživatelů systému k těmto datům.

\section{Klinické testování systému VentConnect}

Prístroj byl uveden do klinického testování v březnu 2021 uprostřed zuř́cí pandemie COVID-19, kdy byla kapacita lůžek JIP rozšírena z 21 na 47 a pracovní zátěž personálu byla extrémní. Na výpomoc byli přijati studenti medicíny a studenti-sestry, a proto zkušený personál navíc dohlížel i na méně zkušený personál. Systém VentConnect byl nainstalován do centrální místnosti

\section{Kouzelné zrcadlo - H: Res II

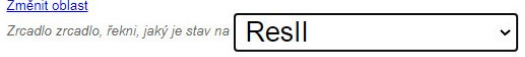

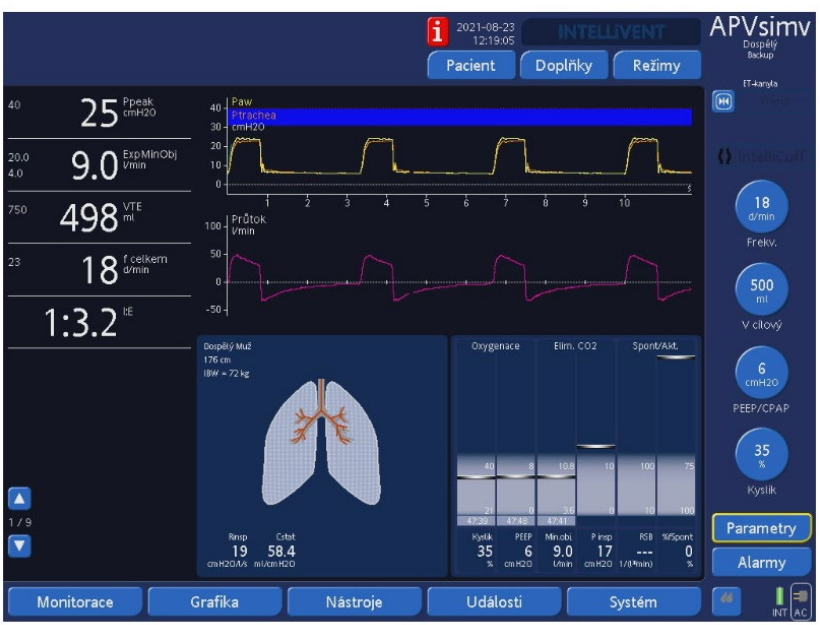

Obrázek 4 - Snímek obrazovky ukazuje obrazovku z webového prohlížeče, kde je možné prohližet nahrané sekvence záznamů z plicních ventilátorů projednotlivé boxy v rámci jednotky intenzivní péče.

lékařů na počítač, takže lékaři mohli na dálku kontrolovat nastavení plicních ventilátorů, aniž by si museli oblékat ochranné pomůcky a vstupovat do klinického prostoru. Zkušenosti lékařu se systémem VentConnect jsme hodnotili v kvalitativní studii prostřednictvím polostrukturovaných telefonických rozhovorů $v$ délce přibližně 30 minut.

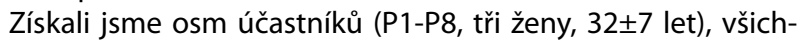
ni lékaři pracující na JIP Fakultní nemocnice FNKV. Všech 8 účastníků zaznamenalo prítomnost systému VENT-CONNECT na JIP-oddělení, kde pracují a systém aktivně používalo. Postoj k užitečnosti systému byl obecně pozitivní. Např́klad osoba P3 uvedla: "Dříve jsme neměli možnost kontrolovat přístroje na dálku, museli jsme kontrolovat každou změnu stavu u lůžka. Použití systému nám usnadnilo život", P4 uvedl: "Je to jako když stojím u prístroje, považuji to za nepostradatelné". Na druhou stranu se objevily obavy, že možnost kontrolovat ventilátory

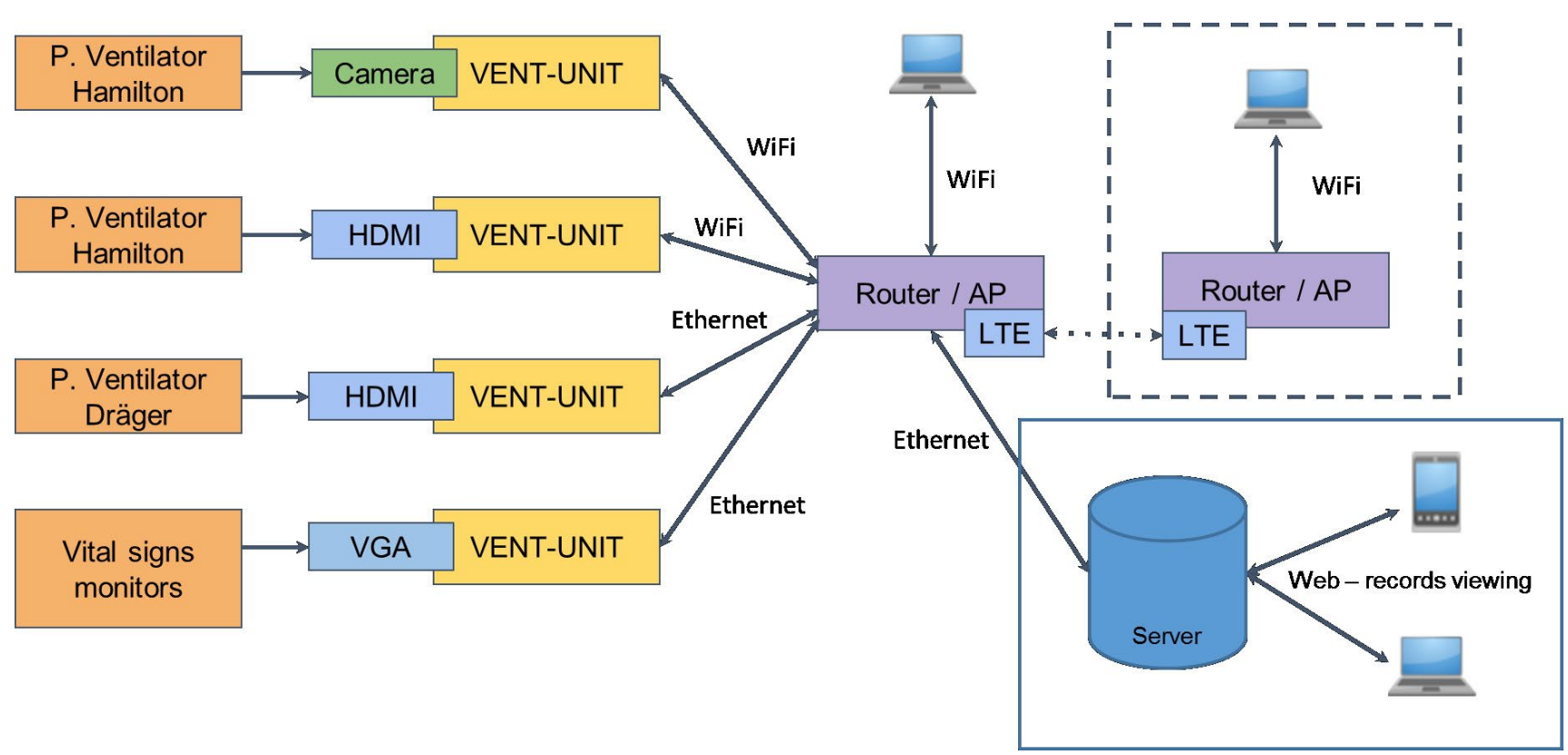

Obrázek 3 - Blokové schéma systému VentConnect z pohledu možných sítových uspořádání včetně serveru pro ukládání nahraných sekvencí záznamů 
odkudkoli může mít negativní psychologické důsledky. Například P7 vyjádřil obavu: "Možná bychom se mohli všichni zbláznit, když kontrolujeme pacienty ve tři hodiny ráno z domova".

\section{Závěr}

Během podzimu a zimy na přelomu let 2020 a 2021 se týmu ČVUT a FNKV podařilo vymyslet a realizovat systém pro sledování obrazovek plicních ventilátorů VentConnect a tento systém začít testovat $v$ klinické praxi v nelehké době pandemie koronaviru. Podařilo se vytvořit užitečný a lékaři obecně kladně hodnocený systém, který má potenciál zlepšit péči o kriticky nemocné pacienty připojené $\mathrm{k}$ monitoru životních funkcí, $\mathrm{k}$ plicnímu ventilátoru, nebo i $k$ dalším přístrojům.

Systém VentConnect budeme i nadále rozvíjet. Stávající verze systému je technické řešení zatím bez jakékoliv inteligence a dalšího usnadnění práce pro lékaře. Naším dlouhodobým cílem je snažit se uplatnit algoritmy zpracování obrazu, rozpoznávání a umělé inteligence tak, aby systém uměl rozpoznat nebezpečné stavy nastavení plicního ventilátoru a upozornit na ně pomocí generování alarmových stavů. Mezitím nás čeká mnoho další práce $v$ oblasti bezpečnosti, vývoje uživatelsky př́větivého systému a prípravy podkladů funkčního prototypu.

\section{Poděkování}

Projekt vznikl za intitucionální podpory ČVUT v Praze a Fakultní nemocnice Královské Vinohrady a za podpory projektu VENT-CONNECT (externí číslo: IDENT022) programu Czech Rise Up 2.0 - Výzkum proti COVID-19.

\section{Literatura}

[1.] [Slutsky 2013] SLUTSKY, Arthur S.; RANIERI, V. Marco. (2013) Ventilator-induced lung injury. New England Journal of Medicine, 369.22: 2126-2136.

[2.] [Dreyfuss 1998] DREYFUSS, Didier; SAUMON, Georges. Ventilator-induced lung injury: lessons from experimental studies. American journal of respiratory and critical care medicine, 1998, 157.1: 294-323.

[3.] [Yasuda 2021] Yasuda H, Sanui M, Nishimura T, Kamo T, Nango E, Abe T, Roberts R, Takebayashi T, Hashimoto S, Lefor AK.Optimal Upper Limits of Plateau Pressure for Patients With Acute Respiratory Distress Syndrome During the First Seven Days: A Meta-Regression Analysis. $J$ Clin Med Res. 2021 Jan;13(1):48-63.

[4.] [Amato, 2015]: Amato MB, Meade MO, Slutsky AS, Brochard L, Costa EL, Schoenfeld DA, Stewart TE, Briel M, Talmor D, Mercat A, Richard JC, Carvalho CR, Brower RG. Driving pressure and survival in the acute respiratory distress syndrome. N Engl J Med. $2015 \mathrm{Feb}$ 19;372(8):747-55.

[5.] [Gattinoni 2001] GATTINONI, Luciano, et al. Effect of prone positioning on the survival of patients with acute respiratory failure. New England Journal of Medicine, 2001, 345.8: 568-573.

[6.] [Costa 2021] Costa ELV, Slutsky A, Brochard LJ, Brower R, Serpa-Neto A, Cavalcanti AB, Mercat A, Meade M, Morais CCA, Goligher E, Carvalho CRR, Amato MBP. Ventilatory Variables and Mechanical Power in Patients with Acute Respiratory Distress Syndrome.

[7.] [Vignaux 2009] VIGNAUX, Laurence, et al. Patient-ventilator asynchrony during non-invasive ventilation for acute respiratory failure: a multicenter study. Intensive care medicine, 2009, 35.5: 840-846.

[8.] [Laffey 2016] Laffey JG et al: LUNG SAFE Investigators and the ESICM Trials Group. Potentially modifiable factors contributing to outcome from acute respiratory distress syndrome: the LUNG SAFE study. Intensive Care Med. 2016 Dec; 42(12):1865-1876.

\section{Kontakt}

Ing. Lenka Vysloužilová, Ph.D. koordinátor projektu na ČVUT České vysoké učení technické v Praze, Český institut informatiky, robotiky a kybernetiky Jugoslávských partyzánů 1580/3 16000 Praha 6 lenka.vyslouzilova@cvut.cz

MUDr. Václav Zvoníček, Ph.D.

Klinika anesteziologie a resuscitace 3. LF UK a FNKV

Fakultní nemocnice Královské Vinohrady Šrobárova 1150/50, Praha 10,

PSČ 10034

vaclav.zvonicek@fnkv.cz

Doc. MUDr. Duška František, Ph.D. odborný garant projektu Klinika anesteziologie a resuscitace 3. LF UK a FNKV

Fakultní nemocnice

Královské Vinohrady

Šrobárova 1150/50, Praha 10,

PSČ 10034

Bc. Jan Jirman; Ing. Jan Kubr, Ph.D.; Ing. Miroslav Macík Ph.D.; Ing. Martin Samek; Jakub Vaněk

České vysoké učení technické v Praze, Fakulta elektrotechnická

Technická 2, 16600 Praha 6 - Dejvice

\section{Ing. Milan Němý}

České vysoké učení technické v Praze, Český institut informatiky, robotiky a kybernetiky Jugoslávských partyzánů 1580/3 16000 Praha 6

Doc. Ing. Lenka Lhotská, CSc. České vysoké učení technické v Praze, Český institut informatiky, robotiky a kybernetiky Jugoslávských partyzánů 1580/3 16000 Praha 6 České vysoké učení technické v Praze, Fakulta biomedicínského inženýrství, nám. Sítná 3105

27201 Kladno 2

Eliška Niebauerová; Bc. Lukáš
Povišer
České vysoké učení technické v Praze,
Fakulta biomedicínského inženýrství,
nám. Sítná 3105
27201 Kladno 2

